\title{
Leachability of Heavy Metals from Autoclaved Fly Ash-Lime Building Bricks
}

\author{
Mehmet TANRIVERDI ${ }^{1)}$, Gül Akar ŞEN ${ }^{\left.1^{*}\right)}$, Tayfun ÇIÇEK ${ }^{1)}$, Sezai ŞEN ${ }^{1)}$, \\ Öznur ÖNEL ${ }^{2)}$
}

\begin{abstract}
1) Dokuz Eylul University, Faculty of Engineering, Dept. of Mining Engineering, Tinaztepe Campus, 35160, Buca-Izmir, Turkey
2) Virginia Polytechnic Institute and State University, Dept. of Mining Engineering, Blacksburg, Virginia, United States

*Correspondence: gul.akar@deu.edu.tr
\end{abstract}

http://doi.org/10.29227/IM-2021-01-09

Submission date: 11-01-2021 | Review date: 23-05-2021

\section{Abstract}

The fly ash as a byproduct of coal-fired power plants constitutes vital ecological problems. In Turkey, approximately 15 million tons of ashes are generated via the combustion of 40 million tons of lignite yearly. Worldwide, a number of investigation and applications were undertaken to utilize fly ash in order to overcome the environmental problems. One of the application area of fly ashes is the production of building bricks. Characterization of fly ash samples from Seyitomer and Yatagan coal-firing power plants were conducted in this study. TCLP 1311, ASTM3987-85 and EN 12457-2 leaching tests on the cylindrical fly ash/lime brick (FA/LB) samples which were produced from Seyitömer and Yatagan thermal power plant fly ash-lime mixtures were performed to determine the leachability of some chosen trace elements. The results show that the release of all trace elements was lower than the hazardous material limit values of waste acceptance. Thus, non- fired fly ash bricks are an advantageous way to solving environmental effect of disposal of fly ashes.

Keywords: coal fly ash, fly ash/lime brick, leaching, trace elements

\section{Introduction}

According to the statistical data, Turkey is in the first ten ranking major countries of the world with coal and lignite production and consumption (http://www.enerji.gov.tr/en-US/ Pages/Coal). The hard coal and lignite reserves of Turkey are 1.3 billion tonnes and 13.9 billion tonnes respectively. Approximately $68 \%$ of the total lignite coal reserves in our country are low calorie and $23.5 \%$ of them are $2000-3000 \mathrm{kcal} / \mathrm{kg}$ (http:// www.enerji.gov.tr/en-US/Pages/Coal).

Turkey's primary energy production totaled 41.8 Mtoe in 2016, of which domestic coal provided 52.7\%. Most of the lignite coal is used in energy production. Energy demand of Turkey has increased twofold over the last two decades, and this trend seems to continue in the future with an average increase of $4 \%$ per year. In the first half of $2018,33 \%$ of Turkey's electricity production of $53,9 \mathrm{TWh}$ was generated in coal-fired thermal power plants (https://euracoal.eu/info/country-profiles/ turkey).

In 2017, power plants created about 10 million tons of residual product. The amount of fly ash ponded near the power plants has reached already 150 million tonnes (Akar,2001; Akar et al, 2010). Therefore, fly ash (FA) destruction, poses a major problem in Turkey. Fly ash is generally classified as hazardous waste because it is contaminated with a small amount of contaminants; including heavy metals. The assessment of the risk arising from FA is of particular importance during its utilization (Liu et al, 2009; Kosson et al., 2000; Ural, 2005; Carlson and Andriano, 2005; ASTMC 204-11, 2005)

Most of the FA derived buildings materials such as concrete, cellular aerated concrete, foam concrete, building bricks, FA stabilized soil and many others will be exposed to rain. Therefore, it is significant to determine the leachability of pollutants such as toxic metals from FA derived materials. Laboratory leaching tests are usually conducted to assess the long-term effect of possibly hazardous constituents on soil, surface and groundwater. They define leach potential of pollutants during the use or discarded mate-rials (Cetin et al., 2012; Cinquepalmi et al., 2008). Unfortunately, there is no standard or accepted method for testing the effect of rain on pollutant leachate from FA and FA derived building materials. Therefore, researchers developed different leaching tests to describe and evaluate the pollutants that could be released from FA. There is a variety of leaching tests with different varia-bles such as solid to liquid ratio $(\mathrm{S} / \mathrm{L})$, chemical reagents, temperature and contact time (Terzic et al., 2012; Johnson et al., 1999). The procedures simulate leaching behavior of coal ash and the results obtained are generally not directly comparable; However, they can show the general mobility of toxic elements in fly ash (Cappuyns and Swennen, 2008; Vitkoca et al., 2009).

The number of the research on description and industrial application of fly ash have enlarged significantly over the years. Consequently, nowadays fly ash can useable in many different sectors (Kosson, 2000, Lea, 1980; Kouskouzas et al., 2010; Lee et al., 2017). Limited amount of FA, primarily for cement and concrete production, is being employed in Turkey. Using FA as a main raw material to make light-weight building bricks is recently investigated with encouraging results (Prinya and Ubolluk, 2018; Çiçek and Cincin, 2015). Re-cently, tests have been done on determining the leachability of heavy metals from FA and FA derived materials (Tanriverdi, 2006; Zermeno et al., 2013; Hjmelmar et al., 2007; Lidelöw and Lagerkvist 2007; Ferreira et al., 2003)).

The objective behind conducting this research work was to study chemical, mineralogical and morphological characteristics of fly ashes and evaluate the extent to which pollutants leach from the autoclaved fly ash/lime bricks (FA/LB). For this purpose, TCLP-1311 method (US-EPA 1992), ASTM D398785 (ASTM 2004) (ASTM, 2004) and one stage water batch test 
Tab. 1 Some physical properties of SOFA and YFA

Tab. 1. Wybrane właściwości popiołów lotnych SOFA i YFA

\begin{tabular}{|l|l|l|l|l|}
\hline & Mean size $\mathbf{( \mu \mathbf { m } )}$ & $\begin{array}{l}\text { Specific gravity } \\
\left(\mathbf{g} / \mathbf{c m}^{\mathbf{3}}\right)\end{array}$ & $\begin{array}{l}\text { Specific surface area } \\
\left(\mathbf{m}^{\mathbf{2}} / \mathbf{g}\right)\end{array}$ & Natural $\mathbf{p H}$ \\
\hline SOFA & 156 & 2.18 & 15.7 & 11.26 \\
\hline YFA & 108 & 2.45 & 3.2 & 12.59 \\
\hline
\end{tabular}

Tab. 2. Chemical composition and trace element concentrations of - $0.212 \mathrm{~mm}$ SOFA and YFA

Tab. 2. Skład chemiczny i zawartości pierwiastków śladowych we frakcji -0,212 mm popiołów SOFA i YFA

\begin{tabular}{|l|l|l|l|l|l|}
\hline $\begin{array}{l}\text { Major } \\
\text { elements } \\
(\%)\end{array}$ & SofA [33] & YFA & $\begin{array}{l}\text { Trace } \\
\text { elements } \\
\text { (mg/kg) }\end{array}$ & SOFA & YFA \\
\hline $\mathrm{SiO}_{2}$ & 56.67 & 52.97 & $\mathrm{As}$ & 95 & 48 \\
\hline $\mathrm{Al}_{2} \mathrm{O}_{3}$ & 17.33 & 18.19 & $\mathrm{Ba}$ & 242 & 233 \\
\hline $\mathrm{CaO}$ & 5.34 & 14.97 & $\mathrm{Cd}$ & 2.7 & 2.3 \\
\hline $\mathrm{MgO}$ & 4.1 & 2.25 & $\mathrm{Co}$ & 5.1 & 7.8 \\
\hline $\mathrm{Na}_{2} \mathrm{O}$ & 0.81 & 0.75 & $\mathrm{Cr}$ total) & 264 & 102 \\
\hline $\mathrm{K}_{2} \mathrm{O}$ & 2.58 & 2.40 & $\mathrm{Cu}$ & 101 & 71 \\
\hline $\mathrm{MnO}$ & 0.1 & 0.04 & $\mathrm{Mo}$ & 1.1 & 1.6 \\
\hline $\mathrm{Fe}_{2} \mathrm{O}_{3}$ & 9.99 & 6.61 & $\mathrm{~Pb}$ & 0.9 & 2.9 \\
\hline $\mathrm{TiO}_{2}$ & 0.14 & 0.25 & $\mathrm{Sr}$ & 159 & 197 \\
\hline $\mathrm{SO}_{3}$ & 1.15 & 0.82 & $\mathrm{Zn}$ & 150 & 98 \\
\hline $\mathrm{Free} \mathrm{CaO}$ & 0.32 & 2.18 & $\mathrm{Ni}$ & 772 & 84 \\
\hline $\mathrm{LOI}$ & 1.75 & 0.71 & $\mathrm{Ag}$ & $<0.2$ & 2.1 \\
\hline
\end{tabular}

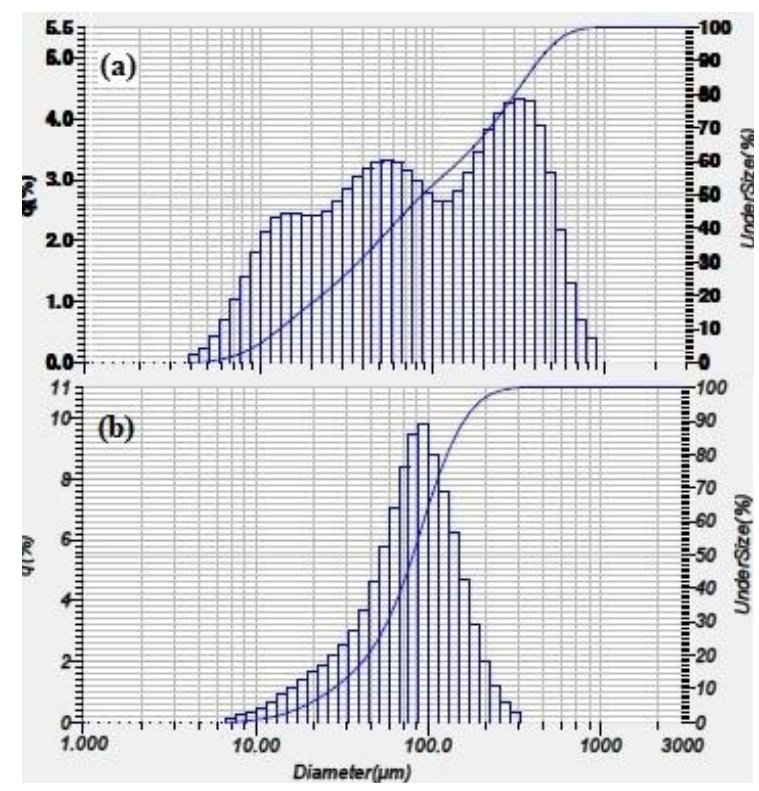

Fig. 1. Size distribution plots of SOFA (a), YFA fly ash (b)

Rys.1. Skład ziarnowy popiołu SOFA(a) i YFA(b)

EN-12457-2 (CEN 2002) (CEN, 2002) were applied on the FA/ LB samples.

\section{Materials and Method}

2.1 Fly ash and fly ash/lime brick samples and characterization

Fly ash samples were taken from two different lignite fired power plants from the western Turkey. The Seyitomer (SO) and Yatagan (Y) power plants use low quality lignite and generate about 0.9 million and 1.1 million ton of fly ash, respectively. Seyitomer fly ash (SOFA) and Yatagan fly ash (YFA) can be categorized as F-class low-lime FA according to ASTM C 618 standard (ASTM 2000). Using a fly ash and quenched lime, a cylindrical fly ash-lime brick (FA/LB) of $45 \mathrm{~mm}$ diameter and
$100 \mathrm{~mm}$ length was made at 12-bar pressure with laboratory size steam autoclave as described by Cicek \& Cincin (2015) .

In this work, particle size analysis of the SOFA and YFA were determined using Horiba brand LA 950 V2 laser diffraction particle size analyzer. The specific surface area of both fly ashes were determined in accordance with ASTM C 20411 (ASTM, 2005). The chemical analysis results of the fly ash samples was conducted using Analytic Jena NovaA 300 AAS. Agilent Technologies 7700 series ICP-MS was used to determine the trace element concentrations. Physical and chemical properties of the SOFA and YFA are tabulated in Table 1. The particle size distributions are shown in Figure 1.

The mineralogical compositions were recognized using Rigaku Miniflex-2 X-ray diffractometer (XRD) at $\mathrm{Cu}-\mathrm{Ka}$ ra- 


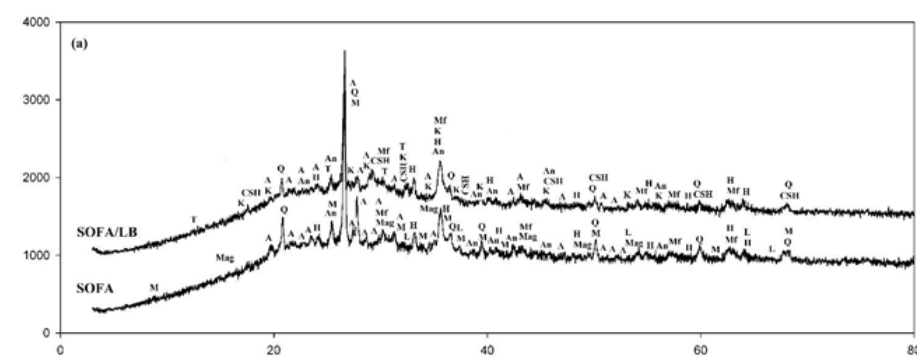

Fig. 2a. XRD analysis results of the FAs and FA/LBs $(\mathrm{A}=$ Anortite, $\mathrm{An}=$ anhydrite, $\mathrm{Q}=$ quartz, $\mathrm{L}=$ lime, $\mathrm{H}=$ hematite, $\mathrm{K}=\mathrm{Katoite}$, $\mathrm{T}=\mathrm{Tobermorite}, \mathrm{CSH}=\mathrm{Cal}$ - um Silicate Hy-drate, $\mathrm{M}=$ Mullite, Mag=Magnetite, $\mathrm{G}=$ Gehlenite, $\mathrm{Mf}=$ Magnosioferrite)

Rys. 2a. Wyniki analizy XRD FA i FA / LB (A = anortyt, An = anhydryt, Q = kwarc, L = wapno, $\mathrm{H}=$ hematyt, $\mathrm{K}=$ katoit, $\mathrm{T}=$ tobermoryt, CSH = hydrat krzemianu wapnia, $\mathrm{M}=$ mulit, Mag = magnetyt, $\mathrm{G}=$ gehlenit, $\mathrm{Mf}$ = magnosioferryt).

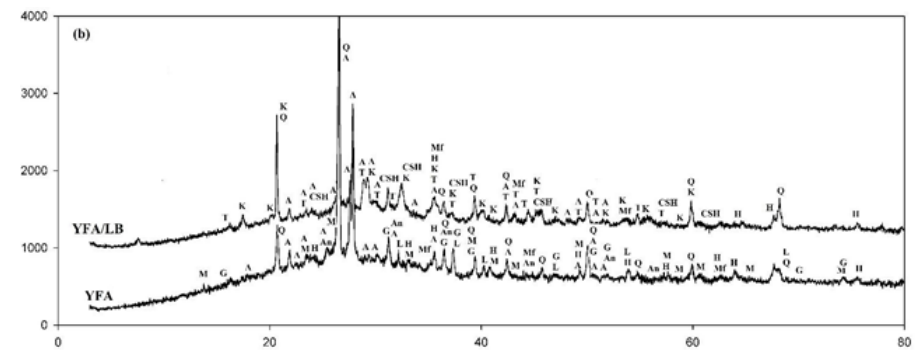

Fig. $2 \mathrm{~b}$. $\mathrm{XRD}$ analysis results of the FAs and FA/LBs ( $\mathrm{A}=$ Anortite, $\mathrm{An}=$ anhydrite, $\mathrm{Q}=$ quartz, $\mathrm{L}=$ lime, $\mathrm{H}=$ hematite, $\mathrm{K}=$ Katoite, $\mathrm{T}=$ Tobermorite, $\mathrm{CSH}=\mathrm{Calci}-$ um Silicate Hy-drate, $M=$ Mullite, Mag=Magnetite, $G=$ Gehlenite, $M f=$ Magnosioferrite)

Rys. 2b. Wyniki analizy XRD FA i FA / LB (A = anortyt, An = anhydryt, $\mathrm{Q}=$ kwarc, $\mathrm{L}=$ wapno, $\mathrm{H}=$ hematyt, $\mathrm{K}=$ katoit, $\mathrm{T}=$ tobermoryt, $\mathrm{CSH}=$ hydrat krzemianu wapnia, $\mathrm{M}=$ mulit, $\mathrm{Mag}=$ magnetyt, $\mathrm{G}=$ gehlenit, $\mathrm{Mf}$ = magnosioferryt)

diation, 30kV, $15 \mathrm{~mA}$. Morphological investigations were conducted with Jeol JXA 733 microprobe, scanning electron microscope (SEM) equipped with energy dispersive spectrometer (EDS)

\subsection{Batch leaching tests}

Mobility of trace elements in fly ash/lime bricks was determined by using serial leaching test, TCLP-1311 method, ASTM D3987-85 and one stage water batch test (EN-12457-2). Each procedure needs the application of specific test conditions. TCLP-1311 method and ASTM D3987-85 were applied on FA/LB samples as described by Akar at al. (Akar et al., 2012). The EN 12457-2 leaching test was carried out at a ratio of L/ $\mathrm{S}=10 \mathrm{~L} / \mathrm{kg}$. A mixed samples, 40g FA/LB samples and $400 \mathrm{ml}$ deionized water, was placed in $500 \mathrm{ml}$ polyethylene bottles. The mixture in the bottles was then shaken for $24 \pm 0.5 \mathrm{~h}$ at $10 \mathrm{rpm}$ in a horizontal oscillating shaker. All the mixtures were kept for 5 minutes, and then the aqueous phase separated by decantation. After the $\mathrm{pH}$ of the leachate was measured, it was filtered through a $0.45 \mathrm{~mm}$ membrane filter paper with a vacuum filtra-tion system and then acidified to $\mathrm{pH}<2$ using high purity nitric acid for analysis. The leached amount of the components was matched with the leaching limit values suggest-ed by the European Council decision 2003/33/EC (C. Decision, 2003).

\section{Results and Discussions}

\subsection{Physical/chemical and mineralogical characterization of Seyitomer and Yatagan fly ashes}

Specific gravities, particle size, specific surface area and $\mathrm{pH}$ are the most important physical and chemical factors for determining the leaching behavior of the pollutants from fly ash (Koukouzaset al., 2011; Akar et al., 2012)].
Figure.1 depicts size distributions for SOFA and YFA. The graph shows that particle size of SOFA is below $0.800 \mathrm{~mm}$ and $0.212-0 \mathrm{~mm}$ fraction makes up $76.06 \%$ of the ash. YFA is below $0.300 \mathrm{~mm}$ and $0.212-0 \mathrm{~mm}$ fraction makes up $84.14 \%$ of the ash. SOFA has a triple modal particle size histogram (Figure. 1a), while YFA has a monomodal distribution (Figure.1b). Some physical properties of SOFA and YFA tabulated in Table 1.

Behavior of trace elements in aqueous environment is related to the natural $\mathrm{pH}$ value of fly ash. The $\mathrm{pH}$ of the slurry obtained by adding $200 \mathrm{ml}$ deionized water and $10 \mathrm{~g}$ fly ash was measured and recorded at 1 hour intervals over a 24 hour period using a WTW brand $\mathrm{pH} / \mathrm{Cond} .320$ portable water meter (Akar et al., 2012). Both fly ashes have the alkaline character, which can be explained by the calcium content being mainly in the form of lime and soluble metal salts, oxides and carbonates. Chemical analysis and trace element concentrations are given in Tables 2 .

Mineralogical properties are another important factor for the leachability of trace ele-ments from fly ash. The XRD analyses on SOFA and YFA in comparison with SOFA/LB and YFA/ LB were performed to determine the mineralogical properties (Figure 2a, Figure 2b).

The crystalline phases were identified by powder X-ray diffraction (XRD) using RIGAKU-Dmax-2200 PC equipment, operating at $30 \mathrm{kV}$ and $15 \mathrm{~mA}$ with $\mathrm{Cu}-\mathrm{Ka}$ radiation. Both fly ash samples contained both the crystal and the amorphous phase. The crystalline phases generally consist of quartz, mullite, lime, iron oxides, etc. The amorphous phases are predominantly made of aluminum. However, some phases contain silica and silicates containing calcium, magnesium and iron at various concentrations. X-ray patterns and assignment of the peaks of the FA and FA/LB are given in Figure. $2 \mathrm{a}$ and Figure. 2b. Ma- 

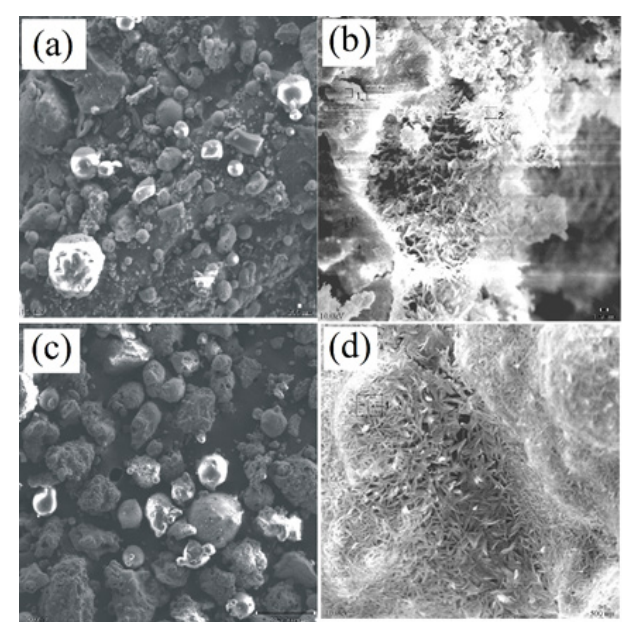

Fig. 3. SEM images of the general view of the SOFA and SOFA/LB (a, b), and of the YFA and YFA/LB (c, d) at different magnification Rys. 3. Obrazy SEM próbek SOFA i SOFA / LB (a, b) oraz YFA i YFA / LB (c, d) przy różnym powiększeniu
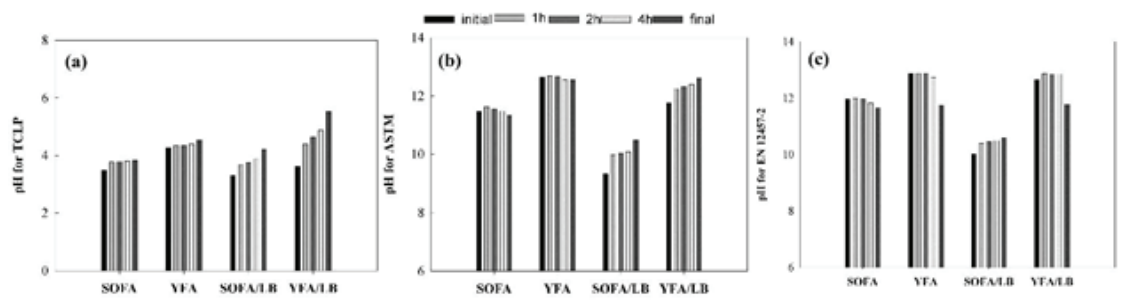

Fig. 4 Results of $\mathrm{pH}$ measurement

Rys. 4. Wyniki oznaczenia odczynu pH

jor crystalline phase of the Seyitömer fly ash was determined as quartz (Figure. 2a). Magnesioferrite is the second dominating mineral. It has small amounts of anorthite, anhydrite, hematite, mullite and lime.

Quartz is found as the major component in the autoclaved SOFA/LB samples. Mullite and lime peaks have disappeared and new phases was occurred such as katoite $\left(\mathrm{Ca}_{3} \mathrm{Al}_{2}\left(\mathrm{Si}_{0.64} \mathrm{O}_{2.56}\right)\right.$ $\left.(\mathrm{OH})_{9.44}\right)$, tobermorite $\mathrm{Ca}_{4}\left(\mathrm{Si}_{6} \mathrm{O}_{15}\right)(\mathrm{OH})_{2}\left(\mathrm{H}_{2} \mathrm{O}\right)_{5}$ and calcium silicate hydrate $2 \mathrm{CaO}\left(\mathrm{SiO}_{2}\right) 2.4\left(\mathrm{H}_{2} \mathrm{O}\right)(\mathrm{Fig} 2 \mathrm{a})$.

As can be seen from Fig. 2b, high content of Quartz $\left(\mathrm{SiO}_{2}\right)$ and anorthite $\left(\mathrm{CaAl}_{2} \mathrm{Si}_{2} \mathrm{O}_{8}\right)$ were found in YFA. Furthermore, minor amounts of hematite $\left(\mathrm{Fe}_{2} \mathrm{O}_{3}\right)$, lime $(\mathrm{CaO})$, gehlenite $\left(\mathrm{Ca}_{2} \mathrm{Al}_{2} \mathrm{SiO}_{7}\right)$, anhydrite $\left(\mathrm{CaSO}_{4}\right)$, hematite $\left(\mathrm{Fe}_{2} \mathrm{O}_{3}\right)$ and mullite $\left(\mathrm{Al}_{6} \mathrm{Si}_{2} \mathrm{O}_{13}\right)$ were observed. Quartz $\left(\mathrm{SiO}_{2}\right)$ was determined as the main crystalline phase of the YFA/LB like SOFA/LB. Similarly, mullite and lime peaks have disappeared in autoclaved YFA/LB samples. Katoite $\left(\mathrm{Ca}_{3} \mathrm{Al}_{2}\left(\mathrm{SiO}_{4}\right) 1.5(\mathrm{OH})_{6}\right)$, tobermorite and calcium silicate hydrate $(\mathrm{CSH})$ were detected in YFA/LB. The formation of calcium silicate hydrates (CSH), and calcium alumino-silicate hydrates (CASH) occurs as a result of pozzolanic reaction of fly ash with lime. Low alkalinity helps the formation of C-S-H phase while the high alkalinity encourages the poorly crystalline $\mathrm{C}-(\mathrm{A})-\mathrm{S}-\mathrm{H}$ phase formation.

Hollow and spherical particles, which are called as cenospheres and small spherical particles within a large glassy sphere, called plerospheres can be seen in Fig. 3. Some clathrosphere particles with partial melting or eroding on their surface can also be seen in Fig. 3a and 3c.

SOFA, generally composed of irregularly shaped particles and agglomerates, also contains in small amount and different sizes of microspheres and irregularly shaped unburned carbon particles. (Fig. 3a). Particle sizes were observed ranged from submicron to greater than $100 \mu \mathrm{m}$. These findings are well matched with the triple modal size distribution plot of SOFA (Fig. 1a). Results of SEM showed that SOFA also contains many porous particles that the particles contain CAS, anhydride and kaolinite. As seen from the Figure 1a irregular agglomerated form of SOFA composed mainly of $\mathrm{CaSO}_{4}$, lime and alkali aluminum silicate composites.

It is very different from the structure of SOFA with the individual spherical particles of YFA. Larger parts of the YFA particles consist of spherical and partially agglomerated particles (Figure 3c). In addition, particle size distributions are in the middle narrow range. This finding is consistent with the size distribution given in figure 1b. SEM photos of FA/LB brick are shown in figure $3 \mathrm{~b}$ and figure $3 \mathrm{~d}$. It is observed that after hydrothermal treatment of FA/LB new crystalline phases were formed. The crystalline phases are shaped on the surface of fly ash particles. They cover the surface of fly ash particles in form of short and long needles. These phases are mainly C-S-H in the form of tobermorite and small amount of katoite as determined also by XRD analyses.

\subsection{Results of leaching potential of the trace elements in the fly ash/lime brick samples}

In this part of the experimental study, typical leaching tests (TCLP 1311, ASTM3987-85 and EN-124572) were conducted to determine the solubility of the trace elements in FA/LB under a weak acid and water environment. 
Tab. 3. The concentration of heavy metals in SOFA/LB and YFA/LB leachate $(\mathrm{mg} / \mathrm{kg})$

Tab. 3. Zawartość metali ciężkich w odciekach SOFA/LB i YFA/LB leachate $(\mathrm{mg} / \mathrm{kg})$

\begin{tabular}{|c|c|c|c|c|c|c|c|c|c|c|}
\hline \multirow{2}{*}{$\begin{array}{l}\mathrm{mg} \\
/ \mathrm{kg}\end{array}$} & \multirow[b]{2}{*}{ TCLP } & \multirow{2}{*}{$\begin{array}{l}\text { SOFA/ } \\
\text { LBS } \\
\text { ASTM }\end{array}$} & \multirow[b]{2}{*}{ EN } & \multirow[b]{2}{*}{ TCLP } & \multirow{2}{*}{$\begin{array}{l}\text { YFA/LBS } \\
\text { ASTM }\end{array}$} & \multirow[b]{2}{*}{ EN } & \multirow{2}{*}{$\begin{array}{l}\text { EPA } \\
\text { max } \\
\text { mg/ } \\
\mathrm{kg}[5 \\
0]\end{array}$} & \multicolumn{3}{|c|}{$\begin{array}{l}\text { Waste acceptance criteria, } \\
\mathrm{mg} / \mathrm{kg} \text { at L/S20 }\end{array}$} \\
\hline & & & & & & & & Inert & $\begin{array}{l}\text { Nonhaz } \\
\text { ardous }\end{array}$ & Hazardous \\
\hline As & ND & ND & ND & ND & ND & ND & 100 & 1 & 4 & 50 \\
\hline $\mathrm{Ba}$ & 15.370 & 0.193 & 0.206 & 28.176 & 11.986 & 17.843 & 2000 & 40 & 200 & 600 \\
\hline $\mathrm{Ca}$ & 25,590 & 4,220 & 3,060 & 82,870 & 6,880 & 5,282 & & & & \\
\hline $\mathrm{Cd}$ & 0.035 & 0.007 & 0.047 & 0.072 & 0.045 & 0.020 & 20 & 0.08 & 2 & 10 \\
\hline Co & 2.942 & ND & ND & 1.3 & ND & ND & & & & \\
\hline $\mathrm{Cu}$ & 5.447 & ND & ND & 0.864 & ND & ND & 300 & 4 & 100 & 200 \\
\hline $\mathrm{Cr}$ & 8.925 & 0.244 & 0.629 & 1.927 & 0.101 & 0.046 & 100 & 1 & 20 & 140 \\
\hline Mo & 0.050 & 0.027 & 0.085 & 1.009 & 0.498 & 0.391 & & & & \\
\hline $\mathrm{Ni}$ & 1.257 & ND & ND & 0.72 & ND & ND & $40 a$ & 0.8 & 20 & 80 \\
\hline $\mathrm{Zn}$ & 10.391 & 0.940 & 0.314 & 0.430 & 0.141 & 0.376 & 500 & 8 & 100 & 400 \\
\hline $\mathrm{Pb}$ & 0.1917 & ND & ND & 0.250 & ND & ND & 100 & 1 & 20 & 100 \\
\hline $\mathrm{Sr}$ & 0.30 & 1.497 & 1.117 & 23.371 & 11.394 & 9.879 & & & & \\
\hline $\mathrm{Fe}$ & 872.381 & 0.45 & ND & 97.027 & 0.256 & ND & & & & \\
\hline $\mathrm{Hg}$ & ND & ND & ND & ND & ND & ND & & 0.02 & 0.4 & 4 \\
\hline $\mathrm{Ti}$ & ND & ND & ND & ND & ND & ND & & & & \\
\hline $\mathrm{Se}$ & ND & ND & ND & ND & ND & ND & & & & \\
\hline
\end{tabular}

a 100x drinking water max, since an EPA-TCLP max has not been established, ND - Not Detected

\subsection{1. pH measurements}

A number of previous studies indicated that leaching behavior of the elements from fly ash samples can change depending on the $\mathrm{pH}$ of the leach solution (Dahl et al, 2008; Iyer, 2002; Valentim et al., 2009; Sasmita et al., 2017). Therefore, the $\mathrm{pH}$ values of the samples were continuously monitored during the test. $\mathrm{pH}$ variations measured during toxicity tests are illustrated in Figure 4.

During the TCLP tests, $\mathrm{pH}$ values of all samples were measured as ranging between 3-5.5 (Figure. 4a). The initial $\mathrm{pH}$ of SOFA, YFA and their FA/LBs are found as lower than final $\mathrm{pH}$ under TCLP test conditions. Initial $\mathrm{pH}$ values of SOFA and YFA under ASTM D3987 and EN-12457-2 test conditions were found as slightly higher than the final $\mathrm{pH}$ values. Both initial and final $\mathrm{pH}$ values of samples for ASTM D3987 test were lower than those of EN-12457-2 mainly due to L/S ratio. As seen from Figure. $4 \mathrm{~b}$ and $4 \mathrm{c}$, the final $\mathrm{pH}$ values of the leachate are changing between 12 and 13.5 for both FA in agreement with the free lime content. Final pH of YFA and YFA/LB was slightly higher than that of SOFA and SOFA/LB due to high free $\mathrm{CaO}$ content of YFA and YFA/LB. Secondary precipitation reactions can occur in the presence of soluble alkali phases (free calcium oxide, soluble metal salts, oxides and hydroxide) in the test sample. This may bound the solubility of some metals (Akar, 2012; Kim, 2006).

\subsubsection{Leachability of toxic elements from autoclaved $F A / L B$}

Fly ash and fly ash derived materials may pose a significant harm to the environment, since some trace elements can contaminate the soil and surface and groundwater, their work is important for environmental protection (Quevauviller et al., 1996; Sloot, 1996). So, the determination of the leaching behavior of trace elements in their form is of prime importance for environ-mental safety.

The leachability of trace elements from the FA/LB samples was investigated using three standard methods (TCLP 1311, ASTM 3987-85 and EN-12457-2). The concentration of the chosen (As, Ba, Cd, Co, Cr, Cu, Mo, Ni, Zn, Pb, Sr, Fe, Hg, Ti, $\mathrm{Se}$ ) in eluates was analyzed by ICP and experiments are given in Table 3.
The leached element ratios (\%) from the fly ash lime brick samples under TCLP (in TCLP test procedure sodium acetate buffer was used at pH 4.99), ASTM D3987 and EN-12457-2 test conditions were given in Figures. 5-6.

Leaching test was performed on FA/LBs showed no presence of $\mathrm{Hg}$, Ti, Ar, Se in investigated samples. Because, in alkaline $\mathrm{FA} / \mathrm{LB}$, as release decline with rising $\mathrm{pH}$. In leaching

In terms of the method, it was seen that the elements were higher in TCLP test conditions. Most of the selected trace elements were leached at higher proportions under TCLP test conditions (Figure. 5 and Figure 6).

It can be seen from the Figure. 5, Ba, Co, Mo, $\mathrm{Zn}$ and $\mathrm{Cu}$ leached in weakly acidic media and were solved at higher amounts in SOFA/LB. Cd, $\mathrm{Cr}, \mathrm{Ni}, \mathrm{Sr}$, and $\mathrm{Pb}$ also show solubility but at very little percentages for SOFA/LB. The solubility ratio of metals in TCLP was greater than the solubility ratio of metals in batch leach test (ASTM and EN) due to the metal solubility generally decreases with increasing $\mathrm{pH}$. The leached elements in deionized water because of the batch leaching tests (ASTM and $\mathrm{EN}$ ) also shown in Figure 5. Ni, $\mathrm{Pb}, \mathrm{Cu}$ and $\mathrm{Cd}$ did not leach from the SOFA/LB. Most of selected elements dissolved relatively low amounts under ASTM and EN test conditions due to the high $\mathrm{pH}$ of the medium. The leachability of $\mathrm{Pb}$ was found to be very low due to the internal glassy matrix form in the sample therefore not readily leached. It is insoluble and constant, independently from the type of leaching test applied. Cadmium is consistently inert in neutral and alkaline mediums. Even though $\mathrm{Cd}$ is connected with the fly ash particles surface, the concentrations leached in water not often exceed the limits (Gould et al., 1989). The leach-ability of $\mathrm{Zn}$ is relatively high for SOFA/LB under TCLP test conditions while, in general, $\mathrm{Zn}$ mobility for both FA/LB is very low (Figure 5 and 6). Copper $(\mathrm{Cu})$ is present within the glassy phase and not easily released. Leachability of $\mathrm{Cu}$ was in between $1.2 \%$ and $5.39 \%$ under TCLP test conditions while it was not leached in both ASTM and EN (Figure. 5 and 6). Nickel (Ni) is dispersed between the silicate fraction and the magnetic fraction of FA during burning process. The majority of the leachable $\mathrm{Ni}$ is released from the non-magnetic fraction. Leached Ni were present in SOFA/LB and YFA/LB under TCLP test conditions, but not present in ASTM and EN. 


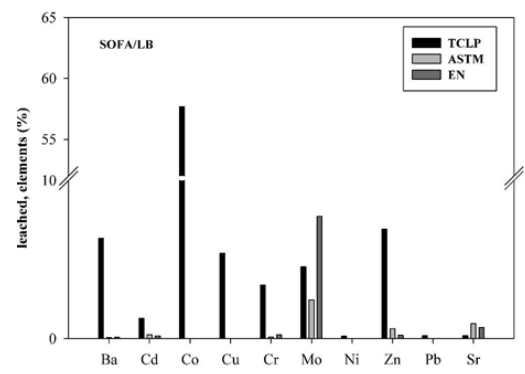

Fig. 5. Results of TCLP, ASTM D3987 and EN-12457-2 from SOFA/LB.

Rys. 5. Wyniki oznaczenia TCLP wg ASTM D3987 i EN-12457-2 w próbce SOFA/LB.

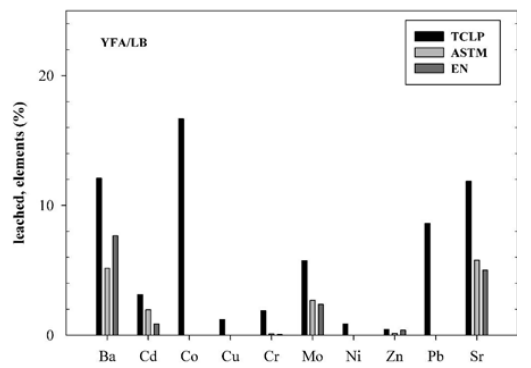

Fig. 6. Results of TCLP, ASTM D3987 and EN-12457-2 from YFA/LB

Rys. 6. Wyniki oznaczenia TCLP wg ASTM D3987 i EN-12457-2 w próbce YFA/LB

\section{Conclusion}

Based on the findings, Seyitomer fly ash sample contains particles below $0.800 \mathrm{~mm}$ particle size and $0.212-0 \mathrm{~mm}$ fraction makes up $76.06 \%$ of the ash. Particle size of Yatagan fly ash sample is found below $0.300 \mathrm{~mm}$ and $0.212-0 \mathrm{~mm}$ fraction makes up $84.14 \%$ of the ash. It is found that both fly ashes have the alkaline character due to lime and soluble metal salts, oxides, hydroxides, and carbonates contents. Quartz $\left(\mathrm{SiO}_{2}\right)$ is found as the main crystalline phase, magnesioferrite $(\mathrm{Mg}$ $\mathrm{Fe}_{2} \mathrm{O}_{4}$ ) is the second dominating mineral and small amounts of anorthite $\left(\mathrm{CaAl}_{2} \mathrm{Si}_{2} \mathrm{O}_{8}\right)$, anhydrite $\left(\mathrm{CaSO}_{4}\right)$, hematite $\left(\mathrm{Fe}_{2} \mathrm{O}_{3}\right)$, mullite $\left(\mathrm{Al}_{6} \mathrm{Si}_{2} \mathrm{O}_{13}\right)$ and lime $(\mathrm{CaO})$ was detected in SOFA samples. Quartz is found as the major component in the autoclaved SOFA/LB samples. Katoite $\left(\mathrm{Ca}_{3} \mathrm{Al}_{2}\left(\mathrm{Si}_{0.64} \mathrm{O}_{2.56}\right)(\mathrm{OH})_{9,44}\right)$, tobermorite $\mathrm{Ca}_{4}\left(\mathrm{Si}_{6} \mathrm{O}_{15}\right)(\mathrm{OH})_{2}\left(\mathrm{H}_{2} \mathrm{O}\right)_{5}$ and calcium silicate hydrate $2 \mathrm{CaO}\left(\mathrm{SiO}_{2}\right) 2.4\left(\mathrm{H}_{2} \mathrm{O}\right)$ were found in brick samples while mullite and lime peaks in fly ash have disappeared. High content of Quartz $\left(\mathrm{SiO}_{2}\right)$ and anorthite $\left(\mathrm{CaAl}_{2} \mathrm{Si}_{2} \mathrm{O}_{8}\right)$ were found in YFA with minor amounts of hematite $\left(\mathrm{Fe}_{2} \mathrm{O}_{3}\right)$, lime $(\mathrm{CaO})$, gehlenite $\left(\mathrm{Ca}_{2} \mathrm{Al}_{2} \mathrm{SiO}_{7}\right)$, anhydrite $\left(\mathrm{CaSO}_{4}\right)$, hematite $\left(\mathrm{Fe}_{2} \mathrm{O}_{3}\right)$ and mullite $\left(\mathrm{Al}_{6} \mathrm{Si}_{2} \mathrm{O}_{13}\right)$. Quartz $\left(\mathrm{SiO}_{2}\right)$ was detected as the main crystalline phase of the YFA/LB like SOFA/LB.
Both FA/LB showed no presence of $\mathrm{Hg}, \mathrm{Ti}$, As and Se in investigated samples. In leaching tests for SOFA / LB and YFA/ $\mathrm{LB}$, the highest solubility was observed in $\mathrm{Ba}, \mathrm{Cr}, \mathrm{Mo}, \mathrm{Cd}$ and Co that is the elements with environmental importance. Most of the selected trace elements were leached at higher proportions under TCLP test conditions due to lower $\mathrm{pH}$ of the eluate. Using lime in production of fly ash bricks helps to establish an alkaline matrix so that the solubility of many toxic elements are prevented. The release of all trace elements was lower than the hazardous material limit values of waste acceptance for land filling stated in the Annex 2 of the 2003/33/CE Council Decision (based on 1999/31/EC Directive) and TCLP-EPA max directive. The study revealed that there would be no environmental risk posed by the presence of pollutants when SOFA and YFA are used as raw materials in FA/LB-making.

\section{Acknowledgements}

This study was supported by the Scientific and Technological Research Council of Tur-key. (TUBITAK, Project No: 111M694). The authors would like to thank to TUBITAK for financial support. 


\section{Literatura - References}

1. Akar G (2001) Determination of Heavy Metal Contamination Resulting from Coal Ash Disposal Areas M.Sc. Thesis. Dokuz Eylul University, Izmir.

2. Akar G, Arslan V, Ipekoglu U, Tekir U (2010) Acid-base production potentials of ash bearing samples from Soma and Yatagan power plants in Turkey, XVI International Coal Preparation Congress. 937-946.

3. Akar G, Polat M, Galecki G, Ipekoglu U. (2012) Leaching behavior of selected trace elements in coal fly ash samples fromYenikoy coal-fired power plants, Fuel Process. Technol. 104 50-56.

4. ASTM (2004) D-3987-85, standard test method for shake extraction of solid waste with water, Annual Book of ASTM Standards; Section 11: Water and Environmental Technology, ASTM D3987-85.

5. ASTM C 204-11 (2005) Standard test methods for fineness of hydraulic cement by air- permeability apparatus, Pennsylvania, United States, 19428-2959.

6. ASTM C 618 (2000) Standard Specification for Coal Fly Ash and Raw or Calcined Natural Pozzolan for Use as a Mineral Admixture in Concrete.

7. Ball MC, Carroll RA (1999) Studies of hydrothermal reactions of UK pulverized ashes. Part 1: reactions between pulverized fuel ash and calcium hydroxide, Adv. Cem. Res. 112 53-61.

8. Bağc1, S.A., Ekiz, H. and Yılmaz, A., 2003. Determination of the salt tolerance of some barley genotypes and the characteristics affecting tolerance. Turkish Journal of Agriculture and Forestry, 27, 253-260.

9. Bayat O. (1998) Characterization of Turkish Fly Ashes. Fuel, 77 1059-1066.

10. C. Decision, 2003/33/EC (2003) Establishing criteria and procedures for the acceptance of waste at landfills pursuant to Article 16 of and Annex II to Directive 1999/31/EC, 11 27-49.

11. Cappuyns V, Swennen R. (2008) The application of $\mathrm{pH}$ stat leaching tests to assess the $\mathrm{pH}$-dependent release of trace metals from soils, sediments and waste materials. J. Hazard. Mater. 158 185-195.

12. Carlson CL, Andriano DC (2005) Environmental impacts of coal combustion residues, J. Environ. Qual. 1993, 22 227-247.ASTM C 204-11, Standard test methods for fineness of hydraulic cement by air-permeability apparatus, Pennsylvania, United States, 19428-2959.

13. CEN (2002) Characterization of waste Leaching Compliance test for leaching of granular waste material and sludge. Part 2: One stage batch test at a liquid to solid ratio of $10 \mathrm{~L} / \mathrm{kg}$ with article size below $4 \mathrm{~mm}$ (without or with size reduction). Brussels: Comite Europeen de Normalisation. EN 12457-2.

14. Cetin B, Aydilek AH, Guney Y (2012) Leaching of Trace metals from high carbon fly ash stabilized highway base layers, Resources, Conservation and Recycling, 58 11, 8-17.

15. Cicek T, Cincin Y (2015) Use of fly ash in production of light-weight building bricks, Construction and Building Materials, 94 521-527.

16. Cinquepalmi MA, Mangialard T, Panei L, Paolini AE, Piga L (2008) Reuse of cement-solidified municipal incinerator fly ash in cement mortars: Physico-mechanical and leaching characteristics, J. Hazard. Mater. 51 (2-3) 585-593.

17. Dahl O, Pöykiö R, Nurmesniemi H (2008) Concentrations of heavy metals in fly ash from a coal-fired power plant with respect to the new Finnish limit values, J. Mater. Cycles Waste Manage. 10 87-92.

18. Ferreira C, Ribeiro A, Ottosen L (2003) Possible applications for municipal solid waste fly ash, J. Hazard. Mater. B96 201-216.

19. Gould JP, Cross WH, Pohland FG (1989) Factors influencing mobility of toxic metals in landfills operated with leachate recycle. In: Emerging technologies in hazardous waste management. ACS symposium series, 422.

20. Hjelmar O, Holm J, Crillesen K. (2007) Utilization of MSWI bottom ash as sub-base in road construction: first results from a large-scale test site. J. Hazard. Mater. A1 39 471-480.

21. Iyer R (2002) The surface chemistry of leaching coal fly ash, J. Hazard. Mater. B 93 321-329.

22. Jiang W, Roy DM (1992) Hydro-thermally processing of new fly ash cement, Ceram. Bull. (4) 642-647.

23. Johnson CA, Kaeppeli M, Brandenberger S, Ulrich A, Baumann W (1999), Hydrological and geochemical factors affecting leachate composition in municipal solid waste incinerator bottom ash. Part II. the geochemistry of leachate from landfill Lostorf, Switzerland. J.Contam. Hydrol. 40 239-259.

24. Jones KB, Ruppert LF, Swanson SM (2012) Leaching of elements from bottom ash, economizer fly ash, and fly ash from two coal-fired power plants. Int. J. Coal Geol. 94 337-348.

25. Kim AG (2006) The effect of alkalinity of Class F PC fly ash on metal release, Fuel, 85 1403-1410.

26. Kosson DS, Van der Sloot HA (2000) WASCON Conference, Putting Theory into Practice, Waste Man. 20(2-3) 113.

27. Koukouzas N, Ketikidis C, Itskos G (2011) Heavy metal characterization of CFB-derived coal fly ash, Fuel Process. Technol. 92 441-446. 
28. Koukouzas N, Vasilatos C, Itskos G, Mitsis I, Moutsatsou A (2010) Removal of heavy metals from wastewater using CFB-coal fly ash zeolitic materials, J. Hazard. Mater. 173 581-588.

29. Lea F. (1980) Lea’s Chemistry of Cement and Concrete, John Wiley \& Sons, London.

30. Lee JK, Ko J, Kim YS. (2017) Rheology of Fly Ash Mixed Tailings Slurries and Applicability of Prediction Models, Minerals 7, 165.

31. Lidelöw S, Lagerkvist A (2007) Evaluation of leachate emissions from crushed rock and municipal solid waste incineration bottom ash used in road construction. Waste Manage. 27 1356-1365.

32. Liu H, Banerji SK, Burkett WJ (2009) Engelenhoven, J.Van Environmental Properties of Fly Ash Bricks, World of Coal Ash (WOCA) Conference. Lexington, KY, USA.

33. Prinya C, Ubolluk R (2018) Fire-resistant geopolymer bricks synthesized from high-calcium fly ash with outdoor heat exposure, Clean Technologies and Environmental Policy, Volume 20, Issue 5, pp 1097-1103.

34. Quevauviller Ph, Sloot HA, Ure A, Muntau H, Gomez A, Rauret G (1996) Conclusions of the workshop: harmonization of leaching/extraction tests for environmental risk assessment, The Sci. Total Environment 178 133-139.

35. Rai A, Mandal AK, Singh KK, Mankhand TR (2013) Preparation and Characterization of Lime Activated Unfired Bricks Made with Industrial Wastes, International J. Waste Resources, Vol. 3(1):40-46.

36. Shi C, Day RL (2000) Pozzolanic reaction in the presence of chemical activators part II. Reaction products and mechanism, Cem. Concr. Res. 30 607-613.

37. Sloot HA (1996) Developments in evaluating environmental impact from utilization of bulk inert wastes using laboratory leaching tests and field verification, Waste Management 16 65-81.

38. Sylvain T, Etoh M, Etame J, Sanjay K (2018) Characterization and Leachability Behaviour of Geopolymer Cement Synthesised from Municipal Solid Waste Incinerator Fly Ash and Volcanic Ash Blends, Recycling 3, 50.

39. Sasmita C.B.,Paul, M.K., Short-term leaching study of heavy metals from LD slag of important steel industries in Eastern India, Journal of Material Cycles and Waste Management, April 2017, Volume 19, Issue 2, pp 851-862.

40. Tanriverdi M. (2006) Toxic elements leachability tests on autoclaved fly ash-lime bricks, Asian J. Chem. 18 $32310-2314$.

41. Terzić A, Radojević Z, Miličić l, Pavlović l, Aćimović Z (2012) Leaching of the potentially toxic pollutants from composites based on waste raw material, Chemical industry \& Chemical engineering quarterly 18 (3) 373-383.

42. Ural S (2005) Comparison of fly ash properties from Afsin-Elbistan coal basin, Turkey, J. Hazard. Mater. B119 85-92.

43. US Environmental Protection Agency (1992) Test Method 1311-TCLP, Toxicity Characteristic Leaching Procedure, Washington, DC., 35 pp.

44. Valentim B, Guedes A, Flores D, Ward CR, Hower CR (2009) Variations in fly ashcomposition sampling location: case study from a Portuguese power plant, Coal Combustion and Gasification Products, 14-24.

45. Valle-Zermeño R, Formosa J, Chimenos JM, Martínez M, Fernánde, A (2013) Aggregate material formulated with MSWI bottom ash and APC fly ash for use as secondary building material. Waste Manag. 33(3) 621-627.

46. Vítková M, Ettle, V, Šebek O, Mihaljevič M, Grygar T, Rohovec J (2009) The pH-dependent leaching of inorganic contaminants from secondary lead smelter fly ash. J Hazard Mater. 167 427-433.

47. Wang H, Jian J, Wang Y, Du W. (2018) Feasibility of Using Gangue and Fly Ash as Filling Slurry Materials, Processes 6, 232.

48. http://www.enerji.gov.tr/en-US/Pages/Coal. (10.09.2018).

49. https://euracoal.eu/info/country-profiles/turkey (14.09.2018).

Wymywalność metali ciężkich z autoklawizowanych cegieł z popiołu lotnego i wapna Popiół lotny jako uboczny produkt spalania w elektrowniach węglowych stanowi istotny problem ekologiczny. W Turcji w wyniku spalania $40 \mathrm{mln}$ ton węgla brunatnego rocznie powstaje około $15 \mathrm{mln}$ ton popiołów. Na całym świecie podjęto szereg badań w celu wykorzystania popiołu lotnego w celu przezwyciężenia problemów środowiskowych. Jednym z obszarów zastosowania popiołów lotnych jest produkcja cegieł budowlanych. W pracy przedstawiono wyniki badania charakterystyki próbek popiołu lotnego z elektrowni węglowych Seyitomer i Yatagan. Przeprowadzono testy ługowania wybranych pierwiastków śladowych, zgodnie z normami TCLP 1311, ASTM3987-85 i EN 12457-2 na cylindrycznych próbkach popiołu lotnego/ cegieł wapiennych (FA / LB), które zostały wyprodukowane z mieszanek popiołu lotnego i wapna w elektrowniach Seyitömer i Yatagan.

Wyniki pokazują, że uwalnianie wszystkich pierwiastków śladowych było niższe niż dopuszczalne wartości dla materiałów niebezpiecznych. Zatem niewypalane cegły z popiołu lotnego są korzystnym sposobem rozwiązania problemu środowiskowego wpływu usuwania popiołów lotnych.

Słowa kluczowe: popiół lotny z węgla, popiół lotny/cegła wapienna, ługowanie, pierwiastki śladowe 